\begin{tabular}{|lccccc|}
\hline $\begin{array}{l}\text { Social Work/Maatskaplike } \\
\text { http://socialwork.journals.ac.za/pub }\end{array}$ & Werk & $\begin{array}{c}\text { Vol } 51 \text { No 1; Issue } \\
\text { doi:http://dx.doi.org/51-1-432 }\end{array}$ & 8 \\
\hline
\end{tabular}

\title{
SOME CHALLENGES OF POLICING DOMESTIC VIOLENCE
}

Ms Rita Retief, (Postgraduate student); Prof Sulina Green, Department of Social Work, Stellenbosch University, Stellenbosch, South Africa

Abstract

Domestic violence is one of the most prevalent forms of violence dealt with by police officers on a daily basis. In order to understand their experiences and response to domestic violence incidents, a purposive sample of twenty-eight police officers in the Western Cape Province were involved in a qualitative phenomenological study. The paper reports on the experiences and challenges of police officers in policing different types of domestic violence. Recommendations on how to equip police officers to deal more effectively with the challenges inherent in domestic violence are offered. 


\title{
SOME CHALLENGES IN POLICING DOMESTIC VIOLENCE
}

\section{Rita Retief, Sulina Green}

\begin{abstract}
Domestic violence is one of the most prevalent forms of violence dealt with by police officers on a daily basis. In order to understand their experiences and response to domestic violence incidents, a purposive sample of twenty-eight police officers in the Western Cape Province were involved in a qualitative phenomenological study. The paper reports on the experiences and challenges of police officers in policing different types of domestic violence. Recommendations on how to equip police officers to deal more effectively with the challenges inherent in domestic violence are offered.
\end{abstract}

\section{INTRODUCTION}

The police, being the frontline social institution to deal with incidents of domestic violence, have a vital role in assisting victims of domestic abuse to follow through on their decision to seek recourse for the abuse (Corcoran, Stephenson, Perryman \& Allen, 2001; Glanz \& Spiegel, 1996). The police not only represent state policy but also act as an important link to both the prosecution process and to the provision of services to victims in a community. Thus, as "gatekeepers" to the criminal justice system, the South African Police Service (SAPS) plays an important role in shaping victims' initial experiences of it. Although for many victims of domestic violence, the police might be a last resort it is often the first point of contact when the victim decides to take that first bold step towards seeking redress.

Most of the literature describing police responses internationally to incidents of domestic violence is critical of police practice (Berk \& Loseke, 1981; Buzawa \& Austin, 1993; Worden \& Pollitz, 1984). The few local research reports that provide insight into the policing of domestic violence in South Africa (Padayachee, 1989; Pretorius, 1987; Van der Hoven, 1989) indicate a high level of dissatisfaction with police assistance and negativity towards the response of police officers.

International studies (Corcoran et al., 2001; Finkelhor, 1988; Gelles \& Strauss, 1999) have pointed out that intervention in domestic violence is a very complex and controversial process as the many potential needs of the victim may be beyond the scope of typical law enforcement tasks. This consequently necessitates multiple intervention approaches and strategies by police officers and external support networks such as social workers. Absent from South African literature on domestic violence are studies that analyse police descriptions of their own experiences in attending to domestic violence incidents. According to Sinden and Stephens (1999) learning about the experiences of police officers is crucial for an understanding of their response to domestic violence incidents. Consequently the aim of the study is to explore police officers' experiences in policing different types of domestic violence. 


\section{RESEARCH DESIGN AND METHOD}

A qualitative research approach together with a phenomenological approach was adopted in the study. Creswell (2003:15) describes the phenomenological approach as a methodology whereby the researcher, through various descriptions provided by participants in a research study is able to identify the "essence" of human experiences concerning a phenomenon. Through this phenomenological study attempts were made to gain a better understanding of the experiences of frontline police officers responsible for the policing of different types of domestic violence incidents. Fouché and Shurink (2011:316) and Whittaker (2009:9) state that phenomenology "...aims to understand and interpret the meaning that subjects give to their everyday lives". This implies that the social phenomenon (domestic violence) will be explained through understanding the way that research participants make sense of their world. A non-probability sampling procedure, common in qualitative studies, was applied with purposive sampling and snowballing techniques being used to select participants.

For this study the total of twenty-eight (28) police officers were identified, based on the following criteria for inclusion: completion of basic training; practical experience in policing of domestic violence incidents; geographical area of the communities they served; and availability of participants (Grinnell \& Unrau, 2008:153). The snowball sampling technique (Strydom \& Delport, 2011:393) was used when some participants of the sample referred the researcher to other potential participants who were subsequently involved in the study. In this way, specific police officers, with practical experience in the policing of the particular phenomenon were identified for inclusion in this study. Data saturation was attained during the in-depth interviews with the twenty-eight (28) research participants (Tutty, Rothery \& Grinnell, 1996:82).

\section{DISCUSSION OF FINDINGS}

The profile of the participants and their experience in policing different types of domestic violence incidents are subsequently presented.

\section{Profile of participants}

The sample $(n=28)$ for this study was drawn from seven police stations identified in the Western Cape Province because of its consistently high statistics for crimes against women and children. The stations ranged from large urban police stations to smaller rural police stations. Four (4) participants were interviewed at each station.

Of the 28 participants, four (14\%) participants held the rank of captain, five (19\%) were warrant officers whilst six $(21 \%)$ participants held the rank of sergeant. The majority of participants in the study, i.e. thirteen (46\%), were constables, accounting for more than double the number of all other ranks represented in the study. This is because all frontline police officers with the rank of constable generally perform duties as "foot soldiers" attending to all complaints received in the charge office as well as at crime scenes.

Participating captains and warrant officers, who (because of their senior rank) normally act as the Community Service Centre (CSC) commanders also generally, had the added 
responsibility of attending to complaints other than requiring police action because of a shortage of personnel. This dual function seemingly had a negative impact on optimal service delivery as participants were required to perform additional roles in terms of service delivery to victims of domestic violence, resulting in diminished attentiveness and lack of sensitivity when dealing with victims of domestic violence - some tended to use shortcuts to help lessen the workload. Three of the CSC commanders confirmed that one shortcut would be to encourage complainants to go back home and "talk things out" with their partners, thus lightening the administrative burden of having to complete the required documentation.

\section{Gender equity}

Gender equity in the SAPS shows great disparity as police officers in the functional (operational) line are still predominantly male. All 28 participants performed shift duties in the CSC or attended to all complaints in the community. Twelve (43\%) of the participants were female and $16(57 \%)$ were male. Female participants seemed to be much more willing to share their perceptions and experiences regarding the policing of domestic violence. Data collected during interviews indicate that female participants found it easier to attend to domestic violence complaints than did their male counterparts.

In terms of race, nine (32\%) of the participants were classified as African, eleven (39\%) coloured and seven $(25 \%)$ white, with only one (4\%) Indian participant. The sample reflects the equity ratio of police officers in the SAPS during 2010/2011. Mark (1996:107) points out that the research sample has to be very similar in demographic terms to the population from which it is drawn, on the variables relevant to the study, for it to be considered representative. Bent-Goodley (2000:327) and Davis (2001:19) found no significant difference between racial groups and the occurrence of domestic violence. Little research is available on the impact of the race of the attending police officer at a domestic violence scene.

\section{Experience in dealing with domestic violence}

The range of experience amongst participants in dealing with domestic violence incidents differed irrespective of rank or years of performing their current duties. Where female participants had not been performing their current duties as long as their male counterparts, they appeared to have had more experience in attending to domestic violence complaints than did their male counterparts. The following statements reflect possible reasons provided by participants:

- "We have an agreement on our shift that sensitive cases where women and children are involved are handled by the female on the shift..."

- "I (male participant) am not so good at dealing with social work problems...women are better at that than us... they are more sensitive than men...

From the above statements it is evident that there is tacit agreement amongst police officers that historically, female officers take the lead when attending to domestic 
violence complaints. This means that female police officers are becoming more skilled at treating domestic violence victims with the necessary dignity and respect while male participants stay inept and tend to have less practical experience in dealing with domestic violence. Male police officers generally tend to take charge of so called "hardcore crimes" whilst their female counterparts mostly handle "social crimes", mainly involving vulnerable victims who are perceived to be more "emotional" and "softer" in nature.

\section{Incidents reported per shift}

The average number of domestic incidents reported per shift can vary from five to 12 depending on the geographical area of the police station. Richards (2002) found that even though actual figures are difficult to obtain, South Africa registers one of the world's highest rates of reported domestic violence. More cases of domestic violence are reported and attended to in urban than in rural areas because of the difference in geographical size and access to resources. It is however evident that there has been an increase in the number of reported incidents of domestic violence in both rural and urban areas. The fact that the incidence is so high echoes findings of LaFevre (1999) that most violence that women are subjected to is still socially, culturally and even legally condoned. All participants however agreed that the number of incidents reported fluctuate, tending to increase depending on the time of the month and is not always recorded but handled "informally".

The findings based on the statistics supplied by participants should be regarded as conservative indications of the actual incidence of domestic violence, as researchers (Singh, 2001; Victor-Zietsman, 2007) and non-profit organisations (Rape Crisis and People Opposing Women Abuse) have for many years documented the discrepancies between reported and actual incidents. Blaser (1998) and Simpson and Kraak (1999) also found that statistics of the SAPS are often associated with significant underreporting because of a lack of public confidence in the police as well as resource challenges which hampers police officers in effectively policing domestic violence.

It is evident that race and rank of participants as well as the size of the respective police station do have an impact on the perceptions and/or experiences of participants as it determines the level of exposure participants get in policing domestic violence.

\section{Types of domestic violence}

Lewis (1999) describes domestic violence as a multi-dimensional phenomenon that involves various types of abuse. At the time of the study all participants were frontline police officers responsible for providing assistance to victims of domestic violence. When analysing the findings it became clear that domestic violence reported by participants takes on many forms. Researchers such as Bassuk, Dawson and Huntington (2005) and Danis and Lee (2003) found that domestic violence generally manifest in physical, sexual, emotional and economic abuse.

When assessing domestic violence, often only physical acts of violence are measured without taking into consideration other forms of violence that may be occurring at the 
same time (Flynn, 1990; James, 1999). The definition of conduct that qualifies as domestic violence was however broadened in the Domestic Violence Act, No. 116 of 1998, to include more than the generally reported abusive behaviours to ensure extended protection in domestic relationships where the victim's safety, health or well-being continued to be in jeopardy.

\section{- Physical abuse}

The Domestic Violence Act, No. 116 of 1998 stipulates that physical abuse includes any deliberate act of physical assault that harms the recipient in any way. It can be a controlled or impulsive act of assault ranging from pushing and slapping to punching, hitting, shoving, biting, choking, burning, kicking, stabbing, shooting and acts or threats of physical violence which are designed to control, hurt or harm the victim.

All participants $(\mathrm{n}=28)$ agreed that physical abuse was the most frequent form of domestic violence dealt with on a daily basis and it was the second most challenging form of abuse to handle. Participants described physical abuse as "difficult", "extremely stressful" and "very problematic" to handle. The level of difficulty for participants in dealing with physical abuse is determined by the consumption of alcohol by parties, having to deal with traumatised children and the perceived ulterior motives of complainants.

Seven (7) of the participants tried to justify the physical abuse meted out to victims ("...woman tends to provoke the man on purpose"). This contradicts the finding of Ferrato (2000) that it is a fallacy that women are looking for abuse or that they provoke it. This assumption by participants in this study also indicates that they are conforming to the current practice of victim-blaming, and the patriarchal perspective of the communities they live in and serve. This supports the statement by Stanko (1998) that regardless changing legislation, some police officers still assume that if a woman is a victim of violence, she must have done something to deserve it.

\section{- Emotional or psychological abuse}

Emotional abuse can be verbal or non-verbal and refers to any pattern of degrading, humiliating and/or demeaning behaviour (Domestic Violence Act, No. 116 of 1998). This kind of abuse tends to be persistent and corrosive in destroying the self-esteem and selfworth of the recipient.

Emotional abuse was noted by more than half (19 or 66\%) of participants as the second most frequent form of abuse encountered by and identified as the most challenging form of abuse to handle. Hagen (2001) found that women exposed to physical violence often also suffer severe emotional and mental distress.

The findings indicate that even though physical abuse is reported more frequently than emotional abuse it does in fact follow that it is the most frequent form of abuse experienced by victims. Furthermore the reason that physical abuse is reported more frequently, is that it is a form of abuse that is often easier for victims to describe because of the visible evidence whereas emotional abuse is reportedly more difficult to prove and 
often not viewed by participants as life threatening. The following statements of participants reflect this:

- “...most difficult to identify as you rarely see any noticeable signs like for physical abuse..."

- “...avoid dealing with emotional abuse as it is problematic to identify elements of a crime...or imminent danger as there is no visible outward signs ..."

The findings show that police officers found emotional abuse extremely challenging to handle because of the lack of visible proof and the psychological manipulation of the victim by the abuser. Browne and Herbert (1997) as well as Sanderson (2008) found that emotional abuse is more difficult to detect than other forms of abuse. Consequently emotional abuse is not always reported or recorded properly.

\section{- Damage to property}

Damage to property is defined in the Domestic Violence Act, No. 116 of 1998 as the wilful damaging or breaking of assets or anything belonging to the victim or in which the victim has a vested interest.

Damage to property was the third most frequently reported form of abuse handled and the fifth most challenging, (out of nine forms of abuse). Damage to property reportedly most often occurs in conjunction with other forms of abuse like physical abuse ("... where both parties are physically violent with each other things tend to get broken in anger ...") as well as where substance abuse is present ("...we always get complaints where furniture is damaged whenever alcohol or drugs are present ...").

One participant indicated that he could not be objective or unbiased in handling this form of abuse because of his own lack of understanding ( "...I find it difficult to understand how you can be guilty of unlawfully damaging your own car..."). This sentiment was also expressed by Flynn (1990) and James (1999) who asserted that some forms of domestic violence are often minimised and treated by police officers as less serious.

\section{- Sexual abuse}

The Domestic Violence Act, No. 116 of 1998 specifies that sexual abuse occurs when there is any unwanted physical invasion of an individual's body that is sexual in nature. This abuse refers to any sexual conduct that does not take the other party's feelings into consideration and is aimed at humiliating, degrading or otherwise violating an individual's integrity. It is also referred to as marital rape whereby one party assumes the right and privilege to have sex whenever he wishes, in any form he desires, without taking the partner's feelings into consideration.

Sexual abuse was identified as the fourth most frequently reported form of abuse and was also indicated as the fourth most challenging for participants to handle. The study found that complaints of marital rape were not often received but on the few occasions a complaint was made it was generally accompanied by other forms of abuse that are often more difficult to prove ("Victims seldom report marital rape... when they do you can be sure there is also emotional abuse or other forms of abuse involved that is not so easy to 
identify..."). This correlates with findings by Parenzee and Smythe (2003) that sexual abuse often goes hand in hand with physical and emotional abuse, but are not reported as frequently by victims. The failure to report all sexual abuse as indicated by the findings is however in contrast with the estimate of Simpson and Kraak (1999:1) that annually at least 1,2 million South African women are likely to be sexually assaulted by someone they know ("In our community victims are too afraid to lay a complaint as a lot of men here still believe it is their right to force their women to have sex..."). This infrequent reporting clearly indicates that sexual abuse continues to be under-reported and subsequently this form of abuse cannot be properly addressed by the police. This finding concurs with Vetten (2005) who noted that rape is under-reported for various reasons.

Even though police officers only seem to be dealing with the tip of the proverbial iceberg regarding sexual abuse, it is evident from the findings that they were being emotionally taxed as they tended to repress their feelings while handling such cases ( $I$ try not to show that it affects me emotionally or that it is difficult to face the victims as the damage is already done"). This also reflects the level of empathy and feelings of helplessness because of an inability to intervene timeously or to prevent this form of abuse.

The study reveals that the level of difficulty in dealing with reported sexual abuse incidents tended to be more emotionally exhausting when it involves the sexual abuse of children by family members or a close family friend ("Sexual abuse cases are more difficult for me when there are children involved...because I feel even more helpless and angry...even at the parents who are supposed to protect their children ..."). This account reflects feelings of helplessness, often exacerbated by an unfulfilled expectation and belief that parents should protect their own - in sharp contrast to what reality they encounter when attending to a domestic violence incident, when feelings of anger are generated towards the supposed cares of children. The findings reveal that it is not easy for police officers to remain neutral and professional at all times as police officers as they could suffer emotional and physical turmoil. The finding is consistent with that of Baker, Jaffe, Berkowitz and Berkman (2002).

\section{- Economic or financial abuse}

Economic and financial abuse involves the unreasonable withholding of economic or financial resources which the victim needs or is entitled to (Domestic Violence Act, No. 116 of 1998). This kind of abuse also refers to any coercive act or limitation on an individual, with adverse economic implications for the victim and any dependants.

Although economic or financial abuse was reported the fifth most frequently encountered form of abuse, it was the third most challenging form of abuse to handle, for the following reasons: "....the victim begs you not to arrest her husband because she will have no income..." and "...victims do not cooperate as they are scared...". It thus appeared that participants were hesitant to act because of the emotional turmoil and financial dependence of the victim. Raphael (2000) found that poverty or unemployment rendered some women more vulnerable to abuse or victimisation than their middle and upper class counterparts. Participants indicated their frustration and feelings of 
hopelessness in the outcome of their encounters with such victims as the intense emotional trauma involved, tended to direct the actions of victims ("... withdraw the case and protection order application because she (victim) feared she would be left without any income...").

\section{- Intimidation}

Intimidation is described in the Domestic Violence Act, No. 116 of 1998 as any verbal or written death threats as well as overt or covert behaviour displayed by the perpetrator which results in the victim being fearful.

Intimidation was named the sixth most frequently encountered form of abuse (out of nine forms) indicated by participants, followed by unauthorised entry of property or premises. Participants generally appeared to view intimidation as very difficult to prove as victims who experienced this form of abuse had difficulty putting a name to what was happening to them and often no action could be taken in this regard. Jewkes (2001) noted that only when victims know what is happening to them will they be better able to take action or get help. None of the participants reported having to deal with intimidation only, as it was always encountered in conjunction with other forms of abuse - most frequently emotional or psychological abuse ("...the fact that complainants are too afraid to lay a charge shows you how confused and traumatised they are because of the threatening behaviour of the abuser...").

It was also evident from findings that this form of abuse is always part of any police perpetrated domestic violence complaint because of the perceived status of police officers ("...victims of police officers are more afraid because they are constantly reminded by the abuser that he has special powers and authority like training and easy access to deadly weapons..."). Wetendorf's (1998) findings confirmed that victims of police perpetrated violence experience additional complications as officers have access to weapons and specialised training to commit violence. From this it can be inferred that the level of intimidation is often increased by a conflicting statement by the perpetrator and the perception by victims that the abuser will be protected by colleagues. Likewise Levinson (1997) and Feltgen (1996) stated that victims of police perpetrated violence often fear reporting the incident to the police as they know the case will be handled by fellow officers who would side with him/her or fail to properly investigate or document the reported incident because of closing of professional ranks.

\section{- Unauthorised entry}

This kind of abuse involves the entering of the home of the victim without her consent where the parties do not share the same home or residence (Domestic Violence Act, No. 116 of 1998).

Unauthorised entry was placed seventh in terms of frequency and was reported to be very problematic to handle. The challenge in handling these incidents seems to centre on victims inviting "...the abuser to move back into the home..." (contrary to stipulations in the protection order) which the abuser is prohibited by law to enter because the victim "...feels sorry for him..." or "... because he threatens her....". This reportedly often 
occurs during the recovering phase of the domestic violence cycle as described by Walker (1984), Landenburger (1998) and Collins (2000) with disastrous results for the victim. Participants in the study also stated that fear and intimidation often serve as motivation for allowing the abuser back into the home ("...he knows she is intimidated by him and his friends..."). This causes great frustration for police officers who find it difficult to convince victims that recovery from the abusive relationship is possible. From these findings it is evident that the "frustration" and "predictability" of the continuous cycle of violence can result in participants becoming disillusioned in their efforts at trying to break the cycle of violence. This in turn has great implications for how successfully future domestic violence complaints will be handled.

\section{- Stalking and harassment}

Stalking is described as abuse that involves the unwanted and repeated following or keeping of the victim under constant surveillance, while harassment involves a pattern of behaviour that causes complainants to fear for their safety and security (Domestic Violence Act, No. 116 of 1998).

Stalking and harassment were indicated as the two forms of abuse least frequently encountered by police officers and therefore least challenging. A possible reason could be that stalking and/or harassment is not classified as a crime and often, like intimidation, difficult to prove. Consequently victims are hesitant to report this form of abuse.

It is evident from the study that the types of abuse participants found the most challenging to handle, were those they encountered most frequently even though the meaning of the incidents of abuse might differ.

\section{CONCLUSIONS AND RECOMMENDATIONS}

- The study offered an overview of police officers' experiences in policing different types of domestic violence. The findings of the study reveal that the types of abuse most frequently handled by police officers are the following in order of frequency: physical abuse, emotional / psychological abuse, damage to property, sexual abuse, economic/financial abuse, intimidation, unauthorised entry, stalking and harassment. In addition emotional abuse, physical abuse, economic abuse, sexual abuse, damage to property and unauthorised entry were the forms of abuse identified as the most challenging to handle.

- Based on the findings the following recommendations are made to equip police officers to deal more effectively with the challenges in addressing domestic violence:

- Police officers as the first point of contact in reported domestic violence incidents should receive annual refresher training courses in dealing with domestic violence and cultural awareness training to assist them in their investigative roles. An environment should be created that encourages and facilitates continuous training focussed on developing skills in tactical thinking, decision-making and optimal performance when confronted with stressful incidents. 
- The appointment of a suitably trained police officer (at every police station) as a coordinator is imperative for the proper monitoring of all domestic violence related incidents. These appointed police officers should be responsible for dealing with all incidents of domestic violence reported at station level and should facilitate the improvement of service delivery to all domestic violence victims.

- Counselling and internal support from the management cadre at every station as well as the Employee Health and Wellness (EHW) professionals should be paramount especially for newly trained recruits to ensure emotional readiness as they will be better able to deal with the complexities of handling domestic violence.

- Police officers should endeavour to establish more effective partnerships with the community which will require of them to make every effort to understand and respond with more sensitivity to the respective expectations of different cultural groups during each police encounter.

- Further research on the experience of frontline police officers in another province should be explored for comparative analysis to determine commonalities and differences in experiences regarding the policing of domestic violence.

\section{REFERENCES}

BAKER, L., JAFFE, G., BERKOWITZ, S. \& BERKMAN, M. 2002. Children exposed to violence: a handbook for police trainers to increase understanding and improve community responses. London: Centre for Children and Families in the Justice System of the London Family Court Clinic, Inc.

BASSUK, E., DAWSON, R. \& HUNTINGTON, N. 2005. Intimate partner violence in extremely poor women: longitudinal patterns and risk markers. Journal of Family Violence, 21(6):387-398.

BENT-GOODLEY, T. 2000. A poor African American community's response to domestic violence. Criminal Justice and Violence, 36(3):327.

BERK, S. \& LOSEKE, D. 1981. Handling family violence: situational determinants of police arrest in domestic disturbances. Law and Society Review, 18:479.

BLASER, D. 1998. Statistics on violence against women in South Africa and internationally. NICRO Women's Support Centre: Women's Net. [Online] Available: http://womensnet.org.za/pvaw/understand/nicrostats.htm.

BROWN, K. \& HERBERT, M. 1997. Preventing family violence. New York: John Wiley and Sons.

BUZAWA, E. \& AUSTIN, T. 1993. Determining police response to domestic violence victims. American Behavioural Scientist, 36(5):610-623.

COLLINS, L. 2000. Teacher to teacher: enhancing adult literacy in the state of Ohio. Ohio: Ohio Literacy Resource Centre. 
CORCORAN, K., STEPHENSON, M., PERRYMAN, D. \& ALLEN, S. 2001. Perceptions and utilization of a police - Social Work crisis intervention approach to domestic violence. Families in Society, 82(4):393-398.

CRESWELL, J. 2003. Research design. Qualitative, quantitative and mixed method approaches $\left(2^{\text {nd }}\right.$ ed). London: Sage Publications.

DANIS, F.S. \& LEE, J. 2003. The criminalization of domestic violence: what social workers need to know. Social Work Journal of the National Association of Social Work, 48(2):145-228.

DAVIS, L. 2001. Why do we still need a women's agenda for Social Work? In: PETERSEN, K. \& LIEBERMANN, A. Building on women's strengths. New York, London, Oxford: Haworth Press, Inc.

FELTGEN, J. 1996. Domestic violence: when the abuser is a police officer. The Police Chief, October: $24-49$.

FERRATO, D. 2000. Living with the enemy. New York: Aperture Foundation.

FINKELHOR, D. 1988. Stopping family violence: research priorities for the coming decade. Newbury Park: CA: Sage Publications.

FLYNN, C. 1990. Relationship violence by women: issues and implications. Family Relations, 39:194-198.

FOUCHÉ, C.B. \& DE VOS, A.S. 2011. Formal formulations. In: DE VOS, A.S., STRYDOM, H., FOUCHÉ, C.B. \& DELPORT, C.S.L. Research at grassroots. For the Social Sciences and Human Service Professions $\left(4^{\text {th }}\right.$ ed). Pretoria: Van Schaik Publishers.

FOUCHÉ, C.B. \& SCHURINK, W. 2011. Qualitative research designs. In: DE VOS, A.S., STRYDOM, H., FOUCHÉ, C.B. \& DELPORT, C.S.L. Research at grassroots. For the Social Sciences and Human Service Professions $\left(4^{\text {th }}\right.$ ed). Pretoria: Van Schaik Publishers.

GELLES, R. \& STRAUS, M. 1999. Intimate violence. New York: Simon \& Shuster.

GLANZ, L. \& SPIEGEL, A. 1996. Violence and family life in a contemporary South Africa: Research and policy issues. Pretoria: HSRC Publishers.

GRINNELL, R. \& UNRAU, Y. 2008. Social work research and evaluation: Foundations of evidence-based practice. New York: Oxford University Press.

HAGEN, J.L. 2001. Women, welfare and violence. A look at the family violence option. In: PETERSEN, K.J. \& LIEBERMAN, A.A. Building on women's strengths. New York, London, Oxford: Haworth Press.

JAMES, K. 1999. Truth or fiction: Men as victims of domestic violence. In: BRECKENRIDGE, J. \& LAING, L. Challenging silence: innovative responses to sexual and domestic violence. St Leonards: Allen \& Unwin. 
JEWKES, R. 2001. Violence against women: an emerging health problem. MRC News, 32(3).

LaFEVRE, I. 1999. Violence against women: a violation of human rights. USA: Institute for Development Training.

LANDENBURGER, K.M. 1998. Exploration of women's identity: Clinical approaches with abused women. In: CAMPBELL, J.C. Empowering survivors of abuse: Health care for battered women and their children. London: Sage Publications.

LEVINSON, A. 1997. Abusers behind a badge. The Arizona Republic, 29 June.

LEWIS, S. 1999. An adult's guide to childhood trauma: understanding traumatised children in South Africa. Cape Town: David Philip Publishers.

MARK, R. 1996. Research made simple: a handbook for social workers. London: Sage Publications.

PADAYACHEE, A. 1989. Wife abuse: an investigation among South African Indian women. KwaZulu-Natal: University of Durban Westville. (Unpublished DPhil dissertation)

PARENZEE, P. \& SMYTHE, D. 2003. Domestic violence \& development: looking at the farming context. University of Cape Town: Institute of Criminology.

PRETORIUS, R. 1987. Gesinsmoord in die Republiek van Suid-Afrika: 'n Misplaaste sin van plig en verantwoordelikheid? South African Journal of Criminal Law and Criminology, 11(2):135-141.

RAPHAEL, J. 2000. Saving Bernice. Boston: North-Eastern University Press.

REPUBLIC IF SOUTH AFRICA (RSA) GOVERNMENT GAZETTE. 1998. No. 116 of 1998: Domestic Violence Act, 19537. Johannesburg: Government Printers.

RICHARDS, M. 2002. Reclaiming women's spaces - new perspectives on violence against women and sheltering in South Africa. Nisaa Institute for women's Development. University of Michigan.

SANDERSON, D. 2008. Counselling survivors of domestic abuse. London: Jessica Kinseley Publishers.

SIMPSON, G. \& KRAAK, G. 1999. The illusions of sanctuary and the weight of the past: Notes on violence and gender in South Africa. Johannesburg: Centre for the Study of Violence and Reconciliation.

SINDEN, P. \& STEPHENS, B. 1999. Police perceptions of domestic violence: the nexus of victim, perpetrator, event, self and law. Policing: An International Journal of Policing Strategies and Management, 22(3):313-327.

SINGH, D. 2001. Human rights and the police in transitional countries: policing vulnerable groups/gender with specific focus on women. Southern Africa: Technikon SA. 
STANKO, E. 1998. Intimate intrusions: women's experience of male violence. London: Routledge \& Kegan Paul.

STRYDOM, H. \& DELPORT, C.S.L. 2011. Sampling and pilot study in qualitative research. In: DE VOS, A.S., STRYDOM, H., FOUCHÉ, C.B. \& DELPORT, C.S.L. Research at grassroots. For the Social Sciences and Human Service Professions $\left(4^{\text {th }}\right.$ ed). Pretoria: Van Schaik Publishers.

TUTTY, L.M., ROTHERY, M.A. \& GRINNELL, R.M. 1996. Qualitative research for social workers: phases, steps and tasks. Boston: Allyn \& Bacon.

VICTOR-ZIETSMAN, M. 2007. Women as victims of violent crime in South Africa. Polsa Bulletin, 1:3-18.

VAN DER HOVEN, A. 1989. Die mishandelde vrou se belewing van geweld. 'n Viktomologiese ondersoek. Pretoria: Universiteit van Suid-Afrika. (DPhil-Proefskrif)

VETTEN. L. 2005. Addressing domestic violence in South Africa: reflections on strategy and practice. South Africa: Centre for the Study of Violence and Reconciliation.

WALKER, L. 1984. The battered woman syndrome. New York: Springer Publishing Company, Inc.

WETENDORF, D. 1998. Police perpetrated domestic violence: battered women justice program. National Centre for Women and Policing. Las Vegas: Nevada.

WHITTAKER, A. 2009. Research skills for Social Work. Great Britain: Learning Matters, Ltd.

WORDEN, R. \& POLLITZ, A. 1984. Police arrests in domestic disturbances: a further look. Law and Society Review, 18:105.

Dr Rita Retief, (doctoral graduate); Prof Sulina Green, Department of Social Work, Stellenbosch University, Stellenbosch, South Africa. 